\title{
Supervisi Akademik Kepala Madrasah di Madrasah Aliyah Darussalam Sumedang
}

\author{
$\operatorname{Dian}^{(1)}$, Ari Prayoga ${ }^{(2)}$ \\ ${ }^{1,2}$ Prodi Manajemen Pendidikan Islam, Program Pascasarjana, Universitas Islam \\ Negeri Sunan Gunung Djati Bandung, Indonesia \\ Email: 1dian@uinsgd.ac.id, 2ariprayoga@madrasah.id
}

\begin{tabular}{l}
\hline Tersedia Online di \\
\hline http://www.jurnal.unublitar.ac.id/in \\
dex.php/briliant \\
\hline \\
\hline Sejarah Artikel \\
\hline Diterima pada 15 November 2019 \\
Disetuji pada 25 November 2019 \\
Dipublikasikan pada 30 November \\
2019 Hal. 548-558
\end{tabular}

Kata Kunci:

Pengawasan; Supervisi Akademik; Madrasah

\section{DOI:}

http://dx.doi.org/10.28926/briliant.v $4 \mathrm{i} 4.413$

\begin{abstract}
Abstrak: Kepala madrasah belum mengambil inisiatif untuk mendekati pengajar untuk mengetahui kendala yang dialami dan belum intensif dalam menerapkan pendekatan klinis. Penelitian ini bertujuan untuk mengungkap proses pengawasan akademik meliputi; merencanakan, melaksanakan dan menindaklanjuti hasil pengawasan di Madrasah Aliyah Darussalam Sumedang, Indonesia. Metode penelitian yang digunakan adalah kualitatif. Teknik pengumpulan data menggunakan wawancara, observasi dan studi dokumentasi. Hasil penelitian menunjukkan bahwa; Pertama, pelaksanaan supervisi akademik dilakukan dengan menyusun program supervisi akademik dan membentuk tim supervisi. Kedua, pelaksanaan supervisi akademik menggunakan pendekatan dan teknik; kunjungan kelas, mengamati kegiatan pengajar, mengamati penguasaan bahan ajar, melakukan diskusi kelompok. Ketiga, menindaklanjuti hasil supervisi akademik pengajar dengan membahas metode pembelajaran, penggunaan dan teknik penilaian, penggunaan media pembelajaran dan penggunaan waktu dalam pembelajaran.
\end{abstract}

\section{PENDAHULUAN}

Supervisi pendidikan ditujukan kepada usaha memperbaiki situasi belajar mengajar yang dimaksud dengan proses belajar mengajar di sini adalah situasi di mana terjadinya proses interaksi antara tenaga pendidik dan peserta didik dalam usaha mencapai tujuan yang optimal. Kualitas pembelajaran sangat dipengaruhi oleh kualitas profesional kinerja tenaga pendidik, oleh karena itu usaha untuk meningkatkan kemampuan profesional tenaga pendidik dalam melaksanakan proses belajar dan mengajar melalui bantuan supervisi, perlu secara terus menerus mendapatkan perhatian dan bantuan profesional dari penanggung jawab pendidikan (Sagala, 2012). Ketika pelaksanaan supervisi dilaksanakan secara intensif oleh kepala madrasah tidak hanya kualitas proses belajar mengajar yang meningkat, akan tetapi kompetensi pendidik pun dapat meningkat. Kualitas tersebut dapat meningkatkan pelayanan pendidikan yang prima kepada peserta didik sebagai konsumen pendidikan.

Kepala madrasah dalam pelaksanaan supervisi menempatkan diri menciptakan suasana dan iklim yang baik, sehingga pelaksanaan supervisi dapat berjalan dengan efektif dan proses belajar berjalan dengan kondusif. Pelaksanaan supervisi dilakukan oleh kepala madrasah dapat berjalan dengan baik dan 
menghasilkan hasil yang optimal apabila pelaksanaan supervisi kepala madrasah dilaksanakan dengan efektif (Mulyasa, 2004). Usaha supervisi kepala madrasah yang berkelanjutan serta konsisten akan menghasilkan sebuah budaya akademik yang baik di madrasah, sehingga hal tersebut menjadi sebuah iklim akademik menuju proses pembelajaran yang berkualitas.

Tabel 1. Pelaksanaan Supervisi Kepada Madrasah MAS Darussalam Sumedang

\begin{tabular}{llll}
\hline No & \multicolumn{1}{c}{$\begin{array}{c}\text { Indikator Supervisi } \\
\text { Akademik }\end{array}$} & $\begin{array}{c}\text { Terlaksana } \\
\text { Terlaksana }\end{array}$ \\
\hline $1 \quad \begin{array}{l}\text { Merencanakan program supervisi akademik dalam } \\
\text { rangka peningkatan } \\
\text { profesionalisme tenaga pendidik }\end{array}$ & $\checkmark$ \\
\hline $2 \quad \begin{array}{l}\text { Melaksanakan supervisi akademik terhadap } \\
\text { tenaga pendidik dengan menggunakan } \\
\text { pendekatan dan teknik } \\
\text { Supervise }\end{array}$ & $\checkmark$ \\
\hline $3 \quad \begin{array}{l}\text { Menindak lanjuti hasil supervisi akademik terhadap } \\
\text { tenaga pendidik dalam rangka } \\
\text { profesionalisme tenaga pendidik }\end{array}$ & $\checkmark$ \\
&
\end{tabular}

Berdasarkan hasil studi dokumentasi data diatas, Kepala Madrasah MAS Darussalam Sumedang telah melaksanakan perannya sebagai seorang supervisor, dengan demikian diharapkan kepala madrasah dapat membantu tenaga pendidik dalam kegiatan proses belajar mengajar. Senada dengan hasil wawancara yang dilakukan penulis kepada tenaga pendidik MAS Darussalam Sumedang bahwa kepala madrasah di MAS Darussalam Sumedang selalu menunjukkan kepribadian yang baik kepada semua tenaga pendidik maupun peserta didik dan seluruh warga madrasah(D.PPSKM, 2019). Pada proses pelaksanaan baik para pendidik atau kepala sekolah memang seringkali menghadapi kesulitan meliputi kontinuitas pelaksanaan supervisi secara akademik dan manajerial.

Dari data tabel diatas, kepala madrasah di MAS Darussalam Sumedang sudah melakukan tugasnya sebagai supervisor akademik dengan baik. Perencanaan program supervisi akademik dalam rangka pengelolaan profesional tenaga pendidik. Menindak lanjuti hasil supervisi akademik terhadap tenaga pendidik dalam rangka profesionalisme tenaga pendidik. Melaksanakan supervisi akademik terhadap tenaga pendidik dengan menggunakan pendekatan dan teknik supervisi tidak sering dilakukan (D.PPSKM, D.PPSKM, Laporan Tabulasi Pelaksanaan Supervisi Kepala Madrasah MAS Darussalam, 2019).

Berdasarkan hasil studi eksplorasi, bahwa pelaksanaan supervisi kepala madrasah di MAS Darussalam Sumedang sudah dilaksanakan, tetapi setelah supervisi akademik yang dilakukan oleh kepala madrasah tidak menimbulkan perkembangan terhadap tenaga pendidik. Ternyata permasalahan yang ada yaitu kepala madrasah belum terlalu intensif dalam melaksanakan pendekatanpendekatan terhadap tenaga pendidik, sehingga pelaksanaan supervisi kepala 
madrasah di MAS Darussalam Sumedang tidak menimbulkan perkembangan terhadap tenaga pendidik (O.LSKM, 2019).

Kepala madrasah yang baik itu bersikap konstruktif terhadap situasi yang sedang berjalan suasana yang menjengkelkan maupun menyenangkan, mencemaskan dan menakutkan, prasangka, dendam. Kemampuan untuk mendengar orang lain dan menghargai pendapat orang lain serta memberi kepercayaan pada tenaga kependidikan akan memberikan kesempatan tenaga kependidikan untuk berkembang, sekaligus memberikan kesempatan kepala madrasah memecahkan problem yang mereka hadapi (Mulyasa, 2004). Peran pendekatan kepala madrasah dalam mempengaruhi pendidik, membuat suasana menjadi kondusif dan memberikan perlakuan klinis adalah langkah strategis dalam pelaksanaan supervisi akademik. Berbagai suasana yang muncul sebelum dan sesudah melaksanakan supervisi harus bisa diprediksi dan dibuat perlakuan tersendiri pada setiap individu pendidik yang berbeda.

Kepala madrasah sebagai pemimpin suatu lembaga pendidikan harus mampu menggunakan tugas dan tanggung jawabnya yaitu bertindak sebagai konsultan bagi tenaga pendidik tenaga pendidik yang mengalami berbagai macam persoalan. Kepala madrasah hendaknya mempunyai kompetensi untuk meningkatkan kemampuan tenaga pendidik dan staf untuk bekerja dan berpikir bersama. Seorang tenaga pendidik tidak hanya dituntut untuk menguasai bidang ilmu, bahan ajar, metode pembelajaran, memotivasi peserta didik, memiliki keterampilan yang tinggi dan mempunyai wawasan yang luas terhadap dunia pendidikan, tetapi juga harus memiliki pemahaman yang mendalam tentang hakikat manusia dan masyarakat. Hakikat-hakikat ini akan melandasi pola pikir dan budaya kerja tenaga pendidik, serta loyalitas terhadap profesi pendidikan.

Disamping itu supervisi kepala madrasah sebagai perangsang keinginan dan daya gerak yang menyebabkan seorang tenaga pendidik bersemangat dalam mengajar karena adanya pembinaan dari kepala madrasah. Tenaga pendidik yang bersemangat dalam mengajar terlihat dalam ketekunannya ketika melaksanakan tugas, ulet, minatnya yang tinggi dalam memecahkan masalah, penuh kreatif dan sebagainya. Hal ini berdampak pada proses kegiatan pembelajaran yang akhirnya mampu menciptakan pembelajaran yang baik.

Supervisi pendidikan berperan memberikan kemudahan dan membantu kepada madrasah dan tenaga pendidik mengembangkan potensi secara optimal. Supervisi harus dapat meningkatkan kepemimpinan kepada sekolah sehingga dapat mencapai efektivitas dan efisiensi program sekolah secara keseluruhan. Dengan demikian, supervisi pendidikan bermaksud meningkatkan kemampuan profesional dan teknis bagi tenaga pendidik, kepada sekolah, dan personel sekolah lainnya agar proses pendidikan di sekolah lebih berkualitas (Wahyudi, 2012). Tidak hanya komponen kelengkapan pembelajaran yang dijaga kualitasnya akan tetapi kompetensi pun terus dilakukan perbaikan secara bertahap. Ketika supervisi memberikan kemudahan bukan menjadi beban kerja kepada pendidik atau kepala madrasah maka hal tersebut sudah menjadi sebuah kebutuhan dan habit pada diri personil lembaga madrasah. Berdasarkan identifikasi dan latar belakang masalah tersebut maka perlu adanya kajian lebih lanjut terkait Supervisi Kepala Madrasah di MAS Darussalam Sumedang. 


\section{METODE}

Jenis penelitian ini adalah penelitian kualitatif, yaitu penelitian yang ditujukan untuk mendeskripsikan data yang telah dikumpulkan berupa kata-kata, tertulis gambar dan bukan angka (Moloeng, 2001). Penelitian ini dilaksanakan di Madrasah Aliyah Darussalam Sumedang Jalan Serma Muchtar Baru Nomor 01, Kelurahan Situ, Kecamatan Sumedang Utara, Kabupaten Sumedang 45323. Adapun alasan peneliti memilih lokasi ini dikarenakan masih kalah kompetitif kualitas pendidikan madrasah aliyah dibandingkan dengan kualitas pendidikan pada sekolah menengah atas lainnnya.

Sumber data primer adalah data yang diperoleh peneliti secara langsung dari tangan pertama yaitu: Kepala Madrasah dan Tenaga pendidik. Sedangkan sumber data sekunder adalah data yang diperoleh peneliti dari sumber yang sudah ada seperti: dokumentasi pelaksanaan supervisi di MAS Darussalam Sumedang, visi dan misi, serta tujuan sekolah dan struktur organisasi, Metode Penelitian Kualitatif, Kuantitatif dan R\&D (Sugiyono, 2012). Metode pengumpulan data meliputi; metode observasi, sebagai pengamatan dan pencatatan dengan sistematik atas fenomena-fenomena yang diteliti (Hadi and Andi, 2004). Observasi sebagai alat untuk mengumpulkan data tingkah laku kepala madrasah dalam melaksanakan supervisi akademik ataupun proses terjadinya kegiatan pelaksanaan supervisi (Ibrahim, 2001). Metode wawancara, pengumpulan data melalui proses tanya jawab lisan yang berlangsung satu arah, antara peneliti kepala madrasah, tenaga pendidik dan kependidikan dan sivitas akademik Madrasah Aliyah Darussalam Sumedang lainnya (Fathoni, 2006). Metode dokumentasi, menyelidiki benda-benda tertulis seperti buku, majalah, dokumen, peraturan-peraturan madrasah, notulen rapat, catatan harian dan lain-lain (Arikunto, 2003).

Dalam pengujian keabsahan data, penelitian ini menggunakan teknik triangulasi, dengan meninjau kebenaran data tertentu dengan data yang diperoleh (Arikunto, 2003); kecukupan referensial, teknik pengujian keabsahan data dengan cara melengkapi pengumpulan data dengan perekam suara, kamera foto, dan kamera video (Buckley and Irawan, 2015). Teknik analisis data sebagai upaya mencari dan menata secara sistematis catatan hasil observasi, wawancara, dan lainnya sebagainya untuk meningkatkan dan memahamkan peneliti tentang supervisi akademik kepala madrasah aliyah Darussalam Sumedang (Tohirin, 2012).

\section{HASIL}

Berdasarkan temuan peneliti di lapangan menunjukan bahwa kegiatan supervisi akademik dilakukan berdasarkan visi, misi dan tujuan madrasah untuk mengelola profesional tenaga pendidik MAS Darussalam Sumedang. Kepala madrasah merencanakan program supervisi akademik diawali dengan menyusun tim supervisi. Tim supervisi terdiri dari Kepala madrasah dan wakil kepala bidang kurikulum diberi surat tugas untuk membantu melaksanakan supervisi akademik.

Tim supervisi yang dibentuk selanjutnya merumuskan tujuan supervisi akademik, menentukan sasaran supervisi akademik, dan membuat jadwal supervisi, serta mempelajari instrumen supervisi yang akan digunakan. Tim supervisi menuangkan rumusan tujuan, sasaran, jadwal, dan instrumen pada program supervisi akademik. Dokumen tersebut akan menjadi dasar dan acuan 
kepala madrasah dan tim supervisi untuk melaksanakan supervisi akademik (W.KM N.Rina Hayati, 2019).

Kepala madrasah menyusun program supervisi akademik setiap tahun di MAS Darussalam Sumedang, dengan menunjuk waka kurikulum untuk menjadi tim supervisi, yang mana tim supervisi akan merumuskan tujuan supervisi akademik, kemudian membuat jadwal dan mempelajari instrumen atau lembar pengamatan yang akan digunakan pada saat supervisi dilaksanakan. Pelaksanaan supervisi yang dilakukan kepala madrasah diawali dengan mengadakan pertemuan awal untuk menetapkan kegiatan supervisi, serta melakukan kunjungan dan observasi terhadap pelaksanaan pembelajaran di kelas, dan diakhiri dengan melakukan pembahasan terhadap temuan yang didapat dari observasi yang dilakukan di dalam kelas (Tim Supervisi, 2019).

Kepala Madrasah melakukan analisis hasil supervisi akademik untuk mengetahui langkah apa yang akan dilakukan selanjutnya terhadap tenaga pendidik. Selain itu, hasil analisis akan dijadikan sebagai bahan pertimbangan kepala madrasah untuk melakukan evaluasi terhadap tenaga pendidik. Tindak lanjut dilakukan di antaranya dengan beberapa hal yaitu membimbing tenaga pendidik dalam pelaksanaan kurikulum di madrasah, mengadakan pertemuan atau rapat, mengadakan diskusi kelompok dan mengadakan penataran-penataran(W. KM.K Dede Komarudin, 2019).

Selain paparan hasil data wawancara dan observasi yang sudah dideskripsikan diatas. Kajian dokumen-dokumen kelengkapan lainnya yang berkaitan dengan supervisi kepala madrasah yaitu perangkat pembelajaran mata pelajaran umum, instrumen supervisi kepala madrasah aliyah Darussalam Sumedang dan dokumen lainnya yang berkaitan baik secara langsung maupun tidak langsung dengan proses supervisi akademik kepala madrasah. Setelah kepala madrasah menyampaikan hasil supervisi kepada tenaga pendidik, untuk hal hal yang sifatnya individu kepala madrasah akan memberikan arahan dan memberikan cara yang benar. Kemudian untuk masalah yang sifatnya umum, kepala madrasah akan merencanakan suatu program kegiatan tindak lanjut (T.P Neneng Mutiara, 2019).

Beberapa temuan yang ada diantaranya dijabarkan dalam beberapa poin pembahasan meliputi; (1) perencanaan dilaksanakan oleh kepala madrasah hanya masih belum maksimal. (2) pelaksanaan belum secara kontinyu dan intensif terlaksana oleh kepala madrasah dan hanya bersifat insidental. (3) tindak lanjut hasil supervisi akademik pengajar dengan membahas metode pembelajaran, penggunaan dan teknik penilaian, penggunaan media pembelajaran.

\section{PEMBAHASAN}

1. Perencanaan Supervisi Akademik

Kepala Madrasah melakukan supervisi dengan kegiatan yang mengacu pada indikator supervisi di antaranya merencanakan program supervisi akademik dalam rangka mengelola profesional tenaga pendidik, melaksanakan supervisi akademik terhadap tenaga pendidik dengan menggunakan pendekatan dan teknik supervisi dan Aspek tindak lanjut hasil supervisi akademik (Nurdiana and Prayoga, 2018). Hal ini dilakukan berdasarkan tahapan dan jadwal pelaksanaan yang telah dibuat oleh kepala madrasah bersama tim supervisi yang dibentuk berdasarkan hasil rapat dewan tenaga pendidik. 
Supervisi diadakan secara rutin, pertama kali kepala madrasah akan memberi surat tugas kepada tenaga pendidik untuk membantu melaksanakan supervisi, selanjutnya kepala madrasah bersama waka kurikulum tersebut akan merumuskan tujuan dan lain sebagainya yang perlu dipersiapkan dalam supervisi akademik. Selanjutnya program itu akan menjadi acuan kepala madrasah beserta tim untuk melaksanakan supervisi akademik (T.P. Cucu Wiliyawati, 2019).

Kepala madrasah dan tim supervisi melaksanakan supervisi akademik dengan menggunakan instrumen penilaian sebagai acuan untuk menilai kinerja tenaga pendidik baik pada bidang administrasi maupun proses kegiatan belajar mengajar di dalam kelas. Pada bidang administrasi, aspek yang dinilai yaitu pada perangkat pembelajaran seperti program tahunan, program semester, silabus, RPP, dan penilaian. Sedangkan pada kegiatan proses belajar mengajar dinilai mulai dari kegiatan awal, kegiatan inti, dan kegiatan penutup (W.KM.K Dede Komarudin, 2019).

Tujuan supervisi akademik yang dilaksanakan di MAS Darussalam Sumedang yaitu (Paramudita and Ridwan, 2019); (1) membantu tenaga pendidik dalam mengembangkan proses pembelajaran supaya tujuan pembelajaran tercapai; (2) mengelola manajemen dan administrasi tenaga pendidik kelas maupun tenaga pendidik mata pelajaran; dan (3) mengevaluasi kinerja tenaga pendidik dalam rangka pembinaan tenaga pendidik. Dasar pertimbangan Kepala madrasah dalam membantu tenaga pendidik adalah hasil pengamatan terhadap kinerja tenaga pendidik dan kompetensi tenaga pendidik terkait dengan penguasaan kelas atau metode mengajar, serta hasil penilaian terhadap pembelajaran yang dilakukan tenaga pendidik mulai dari perencanaan pembelajaran hingga penilaian pembelajaran (W.KM N.Rina Hayati, 2019).

2. Pelaksanaan Supervisi Akademik

Pelaksanaan supervisi dilakukan sebanyak 2 kali yaitu pada awal tahun pelajaran semester ganjil dan semester genap dengan mengacu pada tujuan supervisi yang telah dikemukakan di atas. Adapun jadwal supervisi akademik yang dibuat oleh kepala madrasah bersama tim supervisi berisi keterangan yaitu tenaga pendidik siapa yang akan di supervisi, hari dan tanggal kapan akan diadakan supervisi akademik, mata pelajaran apa tenaga pendidik itu mengajar, pada jam pelajaran ke berapa, dan di kelas mana. Program supervisi akademik mempunyai fungsi sebagai pedoman dalam melakukan dan sekaligus sebagai alat untuk mengukur keberhasilan pembinaan profesional (Irawan, 2016). Dengan program yang baik, maka tenaga pendidik dan kepala madrasah dapat mengetahui masalah-masalah proses pembelajaran apa saja yang dihadapi, cara-cara apa saja yang dapat dilakukan untuk mengatasi masalah itu dan pada akhirnya dapat mengetahui secara sistematis perubahan-perubahan positif apa saja yang terjadi dari waktu ke waktu (Sahmudin and Prayoga, 2019).

Pendekatan supervisi yang diterapkan saat kepala madrasah melaksanakan supervisi akademik belum dicantumkan pada dokumen program supervisi akademik. Pendekatan supervisi yang diterapkan kepala madrasah dapat dilihat dari pelaksanaan supervisi yang dilakukan dengan kunjungan kelas secara rutin, kepala madrasah mengamati para tenaga pendidik untuk melihat proses pembelajaran yang dilakukan oleh tenaga pendidik. Dan juga mengamati metode mengajar yang dipakai oleh tenaga pendidik sehingga mengetahui apakah tenaga 
pendidik tersebut sesuai atau tidak metode pembelajaran yang dipakai (W.KM N.Rina Hayati, 2019).

Kepala madrasah kurang berinisiatif mendekati tenaga pendidik untuk mengetahui kendala yang dialami saat mengajar. Kepala madrasah hanya mengamati proses pembelajaran yang dilakukan oleh tenaga pendidik. Dan kepala madrasah juga tidak menggunakan pendekatan-pendekatan terhadap tenaga pendidik yang mengalami kesulitan dalam mengajar, sehingga tenaga pendidik tidak mendapatkan arahan mengenai masalah yang dihadapi.

Kepala Madrasah melakukan kunjungan kelas untuk melihat dan mengamati proses pembelajaran yang dilakukan oleh tenaga pendidik. Dan juga kepala madrasah mengamati metode pembelajaran yang dipakai oleh tenaga pendidik. Setiap kunjungan kelas selesai dilaksanakan, kepala madrasah memberikan catatan kecil yang ditulis pada buku kunjungan kelas milik tenaga pendidik dan buku supervisi kepala madrasah. Hal ini digunakan untuk mengevaluasi kelemahan, membantu tenaga pendidik dan melakukan perbaikan pada kinerja tenaga pendidik. Kepala madrasah kurang dalam menerapkan pendekatan langsung dan pendekatan tidak langsung. Pendekatan langsung sebenarnya ditunjukkan dengan kepala madrasah yang aktif mendekati tenaga pendidik untuk mengetahui kendala tenaga pendidik dalam pembelajaran. Selain itu, kepala madrasah mengagendakan rapat kepada tenaga pendidik mengenai metode pembelajaran (T.P Cucu Wiliyawati, 2019).

Selanjutnya, pendekatan tidak langsung ditunjukkan oleh tenaga pendidik yang terkadang melaksanakan konsultasi dengan kepala madrasah apabila menemukan kendala dalam proses pembelajaran. Pendekatan supervisi yang diterapkan di MAS Darussalam Sumedang merupakan pendekatan langsung maupun pendekatan tidak langsung. Pendekatan langsung lebih dominan diterapkan dalam pelaksanaan supervisi akademik. Penerapan pendekatan langsung selanjutnya dapat dilihat dari cara kepala madrasah melaksanakan supervisi. Monitoring yang dilaksanakan untuk supervisi dan evaluasi kepala madrasah dengan para tenaga pendidik melakukan kesepakatan sejak awal. Monitoring secara mendadak tanpa memberitahu tenaga pendidik yang bersangkutan, karena untuk mengetahui kesiapan tenaga pendidik apakah benarbenar. Sedangkan untuk analisis dan evaluasi kita lakukan bersama dengan para tenaga pendidik pada saat rapat tenaga pendidik (W.KM N.Rina Hayati, 2019).

3. Tindak Lanjut Hasil Supervisi Akademik

Kepala madrasah dalam melakukan analisis hasil supervisi akademik melibatkan tenaga pendidik, dikomunikasikan bersama dan analisis bersama serta dalam mencari solusinya pun juga bersama-sama. Sedangkan untuk masalah yang sifatnya umum, dibahas melalui rapat dewan tenaga pendidik (W.KM N.Rina Hayati, 2019). Proses selanjutnya dirapatkan bersama kepala madrasah, kepala madrasah akan menyampaikan apa yang beliau amati saat tenaga pendidik mengajar dikelas. Selanjutnya akan dibahas bersama kepala madrasah dengan tenaga pendidik yang bersangkutan, dan nanti akan dibahas mengenai tindak lanjut apa yang akan dilaksanakannya (T.P Elyana Barbera, 2019).

Analisis hasil supervisi akademik dilakukan kepala madrasah bersama tenaga pendidik dengan menganalisa secara bersama-sama hasil supervisi akademik yang dilaksanakan. Hal ini dibuktikan dengan adanya dokumen kepala madrasah berupa program kegiatan workshop MAS Darussalam Sumedang. 
Kepala madrasah sewaktu melaksanakan pengamatan atau monitoring dan pemantauan saat kunjungan atau observasi kelas. Tindak lanjut supervisi akademik yang dilakukan kepala madrasah yaitu membahas mengenai kegiatan pembahasan masalah metode pembelajaran yang disampaikan oleh nara sumber yaitu waka kurikulum, selanjutnya pembahasan mengenai kegiatan penggunaan dan teknik penilaian yang disampaikan oleh narasumber yakni waka kurikulum yang bertempat di tempat MAS Darussalam Sumedang, kemudian tindak lanjut yang dilakukan yaitu dengan melakukan pembahasan mengenai cara penggunaan media pembelajaran yang disampaikan oleh kepala madrasah sendiri yang bertempat di MAS Darussalam Sumedang (Prayoga et al., 2019).

Dalam melakukan analisis hasil supervisi akademik kepala madrasah melibatkan tenaga pendidik, kemudian secara bersama-sama mencari solusi terhadap masalah yang sifatnya umum sehingga masalah yang ada dapat terpecahkan. Analisis hasil supervisi akademik dilakukan kepala madrasah bersama tenaga pendidik dengan menganalisa secara bersama-sama hasil supervisi akademik yang dilaksanakan. Hal ini dibuktikan dengan adanya kegiatan kepala madrasah berupa program kegiatan rapat, seminar atau workshop MAS Darussalam Sumedang (Tim Supervisi, 2019. Pembinaan yang diberikan kepala madrasah yaitu; seminar, workshop, penataran, musyawarah tenaga pendidik matapelajaran (MGMP) dan lain sebagainya. Namun agenda pembinaan terkadang dilakukan oleh kepala madrasah sendiri yang langsung memberikan arahan atau rekomendasi suatu kegiatan kepada para tenaga pendidik (T.P Elyana Barbera, 2019).

Setelah kepala madrasah melakukan analisis dan evaluasi serta melaporkan hasil supervisi akademik, selanjutnya hasil supervisi akademik akan dijadikan dasar pertimbangan dan dimanfaatkan kepala madrasah untuk melakukan pembinaan terhadap tenaga pendidik dalam rangka meningkatkan kinerja tenaga pendidik. Hasil akademik tersebut selanjutnya menjadi dasar kepala madrasah untuk memberikan motivasi dan mengikutsertakan tenaga pendidik dalam kegiatan-kegiatan yang tujuannya untuk mengelola profesionalisme tenaga pendidik. Kepala madrasah memberikan motivasi kepada tenaga pendidik untuk menjadi pendidik yang disiplin dan dijadikan contoh bagi para peserta didik. Selain itu, pemanfaatan hasil supervisi akademik yang selanjutnya adalah kepala madrasah mengikutsertakan atau mengadakan kegiatan yang bertujuan untuk membina tenaga pendidik (Elyana Barbera, 2019).

Sedangkan temuan-temuan yang sifatnya dianggap masalah atau kendala besar, kepala madrasah melakukan diskusi dengan tim supervisi untuk merencanakan bentuk pembinaan yang akan dilakukan untuk mengatasi masalah tersebut dengan mengadakan seminar dan workshop. Kepala madrasah menjalin kerjasama dengan pihak luar madrasah dalam rangka melakukan pembinaan terhadap tenaga pendidik. Kerjasama tersebut dilakukan dalam bentuk mendatangkan narasumber maupun motivator dari pertenaga pendidikan tinggi. Narasumber selanjutnya akan diminta untuk memberikan ceramah terkait dengan pembelajaran seperti cara mengajar, cara memilih materi ajar yang tepat dan lain sebagainya. Selain itu, motivator diminta untuk memberikan dorongan kepada tenaga pendidik agar lebih semangat dalam bekerja. 


\section{KESIMPULAN}

Dari hasil penelitian tentang pelaksanaan supervisi kepala madrasah di MAS Darussalam Sumedang peneliti menyimpulkan bahwa: pertama, pelaksanaan supervisi dilaksanakan dengan cara menyusun program supervisi akademik dan membuat tim supervisi yang diberi tugas untuk membuat tujuan supervisi akademik dan membuat jadwal supervisi akademik. Kedua, pelaksanaan supervisi akademik terhadap tenaga pendidik dengan menggunakan pendekatan dan teknik supervisi seperti melakukan kunjungan kelas untuk mengamati pelaksanaan kegiatan belajar mengajar, mengamati aktivitas tenaga pendidik dalam mengajar, mengamati penguasaan tenaga pendidik terhadap bahan ajar, melakukan diskusi kelompok terhadap para tenaga pendidik untuk membicarakan kurikulum belajar siswa. Ketiga, tindak lanjut hasil supervisi akademik terhadap tenaga pendidik dengan membahas mengenai metode pembelajaran, penggunaan dan teknik penilaian, penggunaan media pembelajaran dan penggunaan waktu dalam pembelajaran. Selanjutnya melakukan analisis hasil supervisi akademik dilakukan kepala madrasah bersama tenaga pendidik dengan menganalisa secara bersama hasil supervisi akademik yang dilaksanakan. Setelah melakukan analisis dan evaluasi serta melaporkan hasil supervisi akademik, selanjutnya hasil supervisi akademik akan dijadikan dasar pertimbangan dan dimanfaatkan kepala madrasah untuk melakukan pembinaan terhadap tenaga pendidik.

\section{SARAN}

Untuk penelitian selanjutnya diharapkan mengembangkan instrumen penelitian pada lokus penelitian multi situs agar memberikan dampak penelitian yang lebih luas. Untuk lembaga yang diteliti untuk meningkatkan pelaksanaan supervisi akademik pada tahap pelaksanaan serta mengadakan Monitoring oleh tim lembaga penjaminan mutu internal di madrasah, sehingga keberlangsungan pelaksanaan supervisi secara konsisten terlaksana.

\section{DAFTAR RUJUKAN}

Arikunto, S. (2003) Prosedur Penelitian Suatu Pendekatan Praktek. Jakarta: Rineka Cipta.

Barbera, E. (2019) 'Wawancara selaku tenaga pendidik B.Indonesia Madrasah Aliyah (MAS) Darussalam Sumedang'. Sumedang: 17 Mei 2019.

Buckley, P. and Irawan, I. (2015) 'The Scientific Paradigm of Islamic Education Management: Phenomenology Perspective', Jurnal Pendidikan Islam, 2(1), pp. 1-29. doi: 10.15575/jpi.v2i1.701.

D.PPSKM (2019) Laporan Tabulasi Pelaksanaan Supervisi Kepala Madrasah MAS Darussalam. Sumedang.

Fathoni, A. (2006) Metodelogi Penelitian dan Teknik Penyusunan Skipsi. Jakarta: Rineka Cipta.

Hadi, S. and Andi (2004) Metode Research. Ed.II. Bandung: Remaja Rosdakarya.

Hayati, N. R. (2019) 'Wawancara Kepala Madrasah Aliyah (MAS) Darussalam Sumedang'. Sumedang: 15 Mei 2019.

Ibrahim, N. S. (2001) Penelitian dan Penilaian Pendidikan. Bandung: Sinar Baru. Irawan (2016) 'Paradigma Keilmuan Manajemen Pendidikan Islam', Manageria: Jurnal Manajemen Pendidikan Islam, 1(2), pp. 297-315. doi: https://doi.org /10.14421/manageria.2016.12-07. 
Kepala Madrasah Bidang Kurikulum (2019) Dokumentasi Instrumen Supervisi Akademik MAS Darussalam Sumedang. Sumedang.

Komarudin, D. (2019) Draft Laporan Evaluasi Supervisi Kepala Madrasah. Sumedang.

Moloeng, L. J. (2001) Metode Penelitian Kualitatif. Bandung: Rosda Karya.

Mulyasa, E. (2004) Menjadi Kepala Sekolah Profesional. Bandung: Remaja Rosdakarya.

Mutiara, N. (2019) 'Wawancara Selaku Tenaga Pendidik Mapel Matematika MAS Darussalam Sumedang'. Sumedang: 17 Mei.

Nurdiana, M. and Prayoga, A. (2018) 'Fungsi-Fungsi Manajemen dalam Kegiatan Ekstrakurikuler Pramuka di Madrasah', Madrasa: Journal of Islamic Educational Management, 1(1), pp. 9-15. Available at: http://madrasa.id/ index.php/madrasa/article/view/2/2.

O.LSKM (2019) Hasil Observasi Supervisi Kepala Madrasah MAS Darussalam. Sumedang.

Paramudita, A. and Ridwan, I. (2019) 'Teknik Supervisi Akademik di Sekolah Islam', Madrasa: Journal of Islamic Educational Management, 2(1), pp. 1-6. doi: 10.32940/mjiem.v2i1.91.

Prayoga, A. et al. (2019) 'Implementasi Penjaminan Mutu Madrasah', Muróbbî: Jurnal Ilmu Pendidikan, 3(1), pp. 70-84. Available at: http://jurnal.iaibafa. ac.id/index.php/murobbi/article/view/183.

Sagala, S. (2012) Supervisi Pembelajaran. Bandung: Alfabeta.

Sahmudin, S. and Prayoga, A. (2019) 'Meningkatkan Kompetensi Pedagogik Pendidik Dalam Pembelajaran Melalui Supervisi Akademik', AlMau'izhoh, 1(2), pp. 12-22. Available at: http://www.jurnal.unma.ac.id/ index.php/am/article/view/1673.

Sugiyono (2012) Metode Penelitian Kualitatif, kuantitatif dan R\&D. Bandung: Alfabeta.

Tim Supervisi (2019) Dokumen Rapat Supervisi Kepala Madrasah MAS Darussalam. Sumedang.

Tohirin (2012) Motode Penelitian Kualitatif dalam Pendidikan dan Bimbingan Konsling. Jakarta: Rajawali Pers.

Wahyudi (2012) kepemimpinan Kepada madrasah Dalam Organisasi Belajar. Bandung: Alfabeta.

Wiliyawati, C. (2019) 'Wawancara selaku tenaga pendidik Sosiologi Madrasah Aliyah (MAS) Darussalam Sumedang’. Sumedang: 16 Mei 2019.

O.LSKM (2019) Hasil Observasi Supervisi Kepala Madrasah MAS Darussalam. Sumedang.

Paramudita, A. and Ridwan, I. (2019) 'Teknik Supervisi Akademik di Sekolah Islam', Madrasa: Journal of Islamic Educational Management, 2(1), pp. 1-6. doi: 10.32940/mjiem.v2i1.91.

Prayoga, A. et al. (2019) 'Implementasi Penjaminan Mutu Madrasah', Muróbbî: Jurnal Ilmu Pendidikan, 3(1), pp. 70-84. Available at: http://jurnal.iaibafa. ac.id/index.php/murobbi/article/view/183.

Sagala, S. (2012) Supervisi Pembelajaran. Bandung: Alfabeta.

Sahmudin, S. and Prayoga, A. (2019) 'Meningkatkan Kompetensi Pedagogik Pendidik Dalam Pembelajaran Melalui Supervisi Akademik', Al- 
Mau'izhoh, 1(2), pp. 12-22. Available at: http://www.jurnal.unma.ac.id/ index.php/am/article/view/1673.

Sugiyono (2012) Metode Penelitian Kualitatif, kuantitatif dan R\&D. Bandung: Alfabeta.

Tim Supervisi (2019) Dokumen Rapat Supervisi Kepala Madrasah MAS Darussalam. Sumedang.

Tohirin (2012) Motode Penelitian Kualitatif dalam Pendidikan dan Bimbingan Konsling. Jakarta: Rajawali Pers.

Wahyudi (2012) kepemimpinan Kepada madrasah Dalam Organisasi Belajar. Bandung: Alfabeta.

Wiliyawati, C. (2019) 'Wawancara selaku tenaga pendidik Sosiologi Madrasah Aliyah (MAS) Darussalam Sumedang’. Sumedang: 16 Mei 2019. 